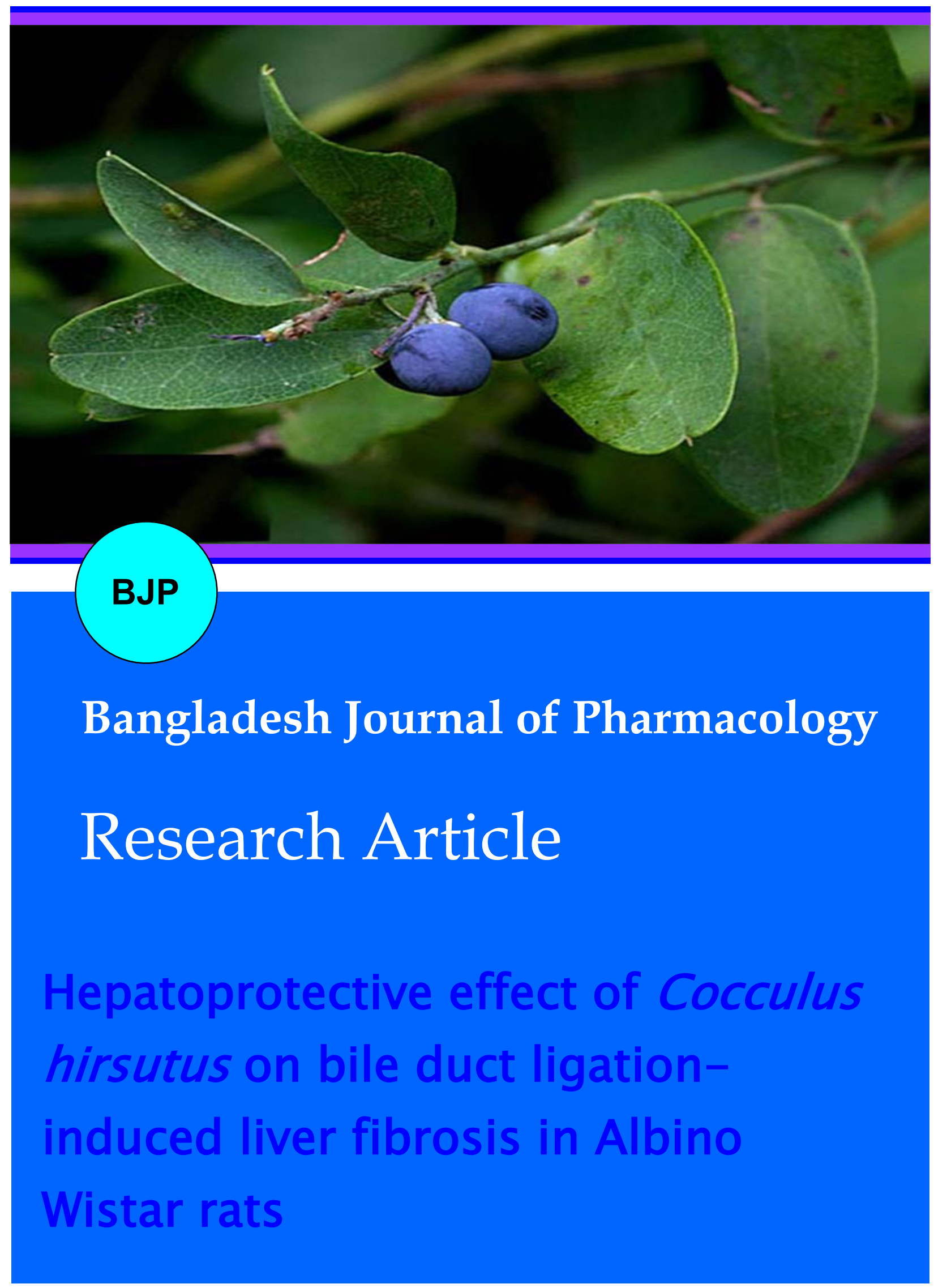




\title{
Hepatoprotective effect of Cocculus hirsutus on bile duct ligation- induced liver fibrosis in Albino Wistar rats
}

\author{
Sagar P. Thakare'1, Hitesh N. Jain'1, Savita D. Patil² and Umesh M. Upadhyay' \\ ${ }^{1}$ Department of Pharmacology, Sigma Institute of Pharmacy, Bakrol, Waghodia, Baroda, Gujarat, India; ${ }^{2}$ Department \\ of Pharmacology, R. C. Patel Institute of Pharmacy, Shirpur, Dhule, Maharashtra, India.
}

\begin{tabular}{|c|c|}
\hline Article Info & \\
\hline $\begin{array}{l}\text { Received: } \\
\text { Accepted: } \\
\text { Available Online: }\end{array}$ & $\begin{array}{r}5 \text { August } 2009 \\
3 \text { September } 2009 \\
6 \text { September } 2009\end{array}$ \\
\hline DOI: $10.3329 /$ bjp.v & ti2.2980 \\
\hline $\begin{array}{l}\text { Cite this article: } \\
\text { Thakare SP, Jain } \\
\text { Upadhyay UM. } \\
\text { effect of Cocculus hi } \\
\text { ligation-induced liv } \\
\text { no Wistar rats. Ban } \\
\text { col. 2009; 4: 126-30. }\end{array}$ & $\begin{array}{l}\text { HN, Patil SD } \\
\text { Hepatoprotective } \\
\text { rsutus on bile duc } \\
\text { er fibrosis in Albi } \\
\text { gladesh J Pharma }\end{array}$ \\
\hline
\end{tabular}

\section{Abstract}

In this animal model (Wistar rats of either sex), common bile duct was ligated for 28 days. Rats were treated for 28 days with methanol extract of Cocculus hirsutus. On day 29, blood and liver were collected for biochemical estimation and histopathological studies. Bile duct ligation produced liver fibrosis with generation of reactive oxygen species and induction of oxidative stress. Hence the different concentrations of methanolic extract of $C$. hirsutus were evaluated for in vivo glutathione reductase activity. On bile duct ligation the liver fibrosis was induced with significant rise in serum marker enzymes levels. The hydroxyproline accumulation caused by hydrophilic bile acids accompanied by elevated hepatic lipid peroxidation, and glutathione levels. Treatment with C. hirsutus extract decreased the elevated levels of serum marker enzymes showing hepatoprotection, which was further confirmed by histopathological results.
\end{abstract}

\section{Introduction}

Bile duct ligation is a typical model of biliary disease in animals, which features proliferation of bile duct epithelial cells, hepatocellular necrosis, apoptosis, stellate cell activation and eventually the formation of liver fibrosis and cirrhosis. Bile duct ligation has been associated with hepatic mitochondrial proteins and lipids and cytotoxicity of bile components such as lipophilic bile acids. The bile salts are partly responsible for the plasma membrane damage seen in bile-duct ligated models which leads to further oxidative stress (Wang et al., 2007).

Liver fibrosis is major features of a side range of chronic liver injury including metabolic, viral, cholestatic and genetic disease. The failure of bile salt excretion in cholestasis leads to retention of hydrophobic bile salts within the hepatocytes and causes apoptosis and necrosis (Lee et al., 2007). Bile duct ligation produces the lipid peroxidation in cellular membranes that induces cell injury and decreased in glutathione indicating importance of free radical which damages the defense system in body.

Cocculus hirsutus (L) belonging to family Menispermaceae is a perennial climber mainly found in tropical and subtropical climatic condition (Panda and Mishra, 2007). The root destroys kapha and vata lessens bile (Kirtikar and Basu, 1987). The C. hirsutus shows hypoglycemic activity (Ganapaty and Bijay, 2006), diuretic, laxative activity (Ganapaty et al., 2002), hypolipidemic activity (Palsamy et al., 2007) and spermatogenic activity (Jayakar and Sangameswaran, 2007). Folk medicine claim that it may be used in jaundice.

We still do not have any specific agent for hepatoprotection. However, several studies suggest that some herbal plants such as Spirulina maxima (Torres -Durain et al., 1999), Eclipta alba (Saxena et al., 1993), Boehmeria nivea (Lin et al., 1998), Cichorium intybus (Zafar and Ali, 1998), Picrorhiza kurrooa (Saraswat et al., 1999), Trianthema decandra (Balamurugan and 
Muthusamy, 2008), and Phyllanthus niruri (Iqbal et al., 2007) etc. have hepatoprotective effects.

The literature survey revealed that there are no scientific studies carried out on hepatoprotective activity of the $C$. hirsutus. Hence, the present study is focused to evaluate the hepatoprotective and antioxidant potentials of the plant against bile duct ligationinduced liver fibrosis albino Wistar rats.

\section{Materials and Methods}

Collection and authentication of plant: The plant was collec -ted from local area of Shirpur, Dhule Maharashtra, India. The plant was authenticated by Dr. D.A. Patil, Department of Botany, S.S.V.P.S College of Science, Dhule, Maharashtra, India.

Extraction methodology: The plant was air dried, cut into small pieces and pulverized into powder. Five hundred gram of dried, powdered plant material was extracted with petroleum ether $\left(60-80^{\circ} \mathrm{C}\right)$ using soxhlet apparatus to remove lipids. It was then filtered and filtrate was discarded. The residue was then extracted successively with methanol using soxhlet apparatus and methanol was evaporated in a rotary evaporator at $40-50^{\circ} \mathrm{C}$ under reduced pressure. The residual extract was suspended in water for overnight and filtered. The filtrate was dried and stored. The yield of extract was 20\% with reference to dry starting material (Palsamy and Malathi, 2007).

The phytochemical investigation was performed according to Kokate and Purohit, 2004.

Experimental animals: Three months old Wistar Albino rats of either sex weighing 150-250 g were used for the study. The animals were procured from animal house of R.C. Patel IPER Shirpur. The animals were placed at random and allocated to treatment groups in polypropylene cages with paddy husk as bedding. Animals were housed at a temperature of $24 \pm 2{ }^{\circ} \mathrm{C}$ and relative humidity of $30-70 \%$. A light and dark cycle was followed. All animals were fed on standard balanced diet and provided with water ad libitum.

All the experimental procedures and protocols used in the study were reviewed and approved by the (IAEC) Institutional Animal Ethical Committee of R.C. Patel IPER, Shirpur and were in accordance with the guidelines of the Committee for the Purpose of Control and Supervision of Experiments on Animals (CPCSEA). Registration No.RCPCOP/IAEC/2007-2008/30.

Toxicity study (OECD 425): Acute oral toxicity was conducted for methanol extract on albino mice according to OECD 425 and median effective dose $\left(E_{50}\right)$ of extract was selected based on $\mathrm{LD}_{50}$ obtained from acute toxicity studies.

Bile duct ligation induced liver damage (Vogel and Vogel, 2002): Rats were anesthetized with ketamin and
Table I

Physical parameters in bile duct ligation animals

\begin{tabular}{|lcc|}
\hline Groups & $\begin{array}{c}\text { Liver } \\
\text { weight }(\mathrm{g})\end{array}$ & $\begin{array}{c}\text { Liver vol- } \\
\text { ume (mL) }\end{array}$ \\
\hline Normal & 8.5 & 7.6 \\
Bile duct ligated & 12.4 & 11 \\
$\begin{array}{l}\text { Bile duct ligated + Silymarin } \\
(50 \mathrm{mg} / \mathrm{kg})\end{array}$ & 9.5 & 7.6 \\
$\begin{array}{l}\text { Bile duct ligated + Methanol } \\
\text { extract of Cocculus hirsutus } \\
(100 \mathrm{mg} / \mathrm{kg})\end{array}$ & 9 & 8.5 \\
$\begin{array}{l}\text { Bile duct ligated + Methanol } \\
\text { extract of Cocculus hirsutus } \\
(200 \mathrm{mg} / \mathrm{kg})\end{array}$ & 12 & 11.7 \\
$\begin{array}{l}\text { Bile duct ligated + Methanol } \\
\text { extract of Cocculus hirsutus } \\
(400 \mathrm{mg} / \mathrm{kg})\end{array}$ & 10.8 & 11.3 \\
\hline
\end{tabular}

diazepam. Laparatomy was performed under antiseptic conditions. A midline incision in the abdomen was made from the xiphosternum to the pubis, exposing the muscle layers and the linea alba, which was then incised over a length corresponding to the skin incision. The edge of the liver was then raised and the duodenum pulled down to expose the common bile duct, which pursues an almost straight course of about $3 \mathrm{~cm}$ from the hilum of the liver to its opening into the duodenum. There was no gall bladder, and the duct was embedded for the greater part of its length in the pancreas, which opens into it by numerous small ducts. A blunt aneurysm needle was passed under the part of the duct selected, stripping the pancreas away with care, and the duct was divided between double ligatures of cotton thread. The peritoneum and the muscle layers as well as the skin wound were closed with cotton stitches.

All animals were grouped as follows containing six animals in each group. The animals of Group I received only distilled water for 28 days. The bile ducts of animals of Group II were ligated for 28 days. In Group III the standard drug silymarin (50 mg/ $\mathrm{kg}$ ) was administered in bile duct ligated animals. In Group IV, Sham operated rats had their bile duct exposed but not ligated or sectioned.

Group V, Group VI, Group VII, underwent bile duct ligation surgery followed by simultaneous administration of three different doses of methanol extract of $C$. hirsutus (100, 200 and $400 \mathrm{mg} / \mathrm{kg}$ ) respectively for 28 days.

Biochemical estimations: On day 29, blood was withdrawn from all groups of rats by puncturing retroorbital plexus. The blood samples were allowed to coagulate at room temperature. Serum was separated by centrifugation at 3,000 rpm at room temperature for $20 \mathrm{~min}$ and subjected to biochemical estimations serum 
transaminases, alkaline phosphatase, lactate dehydrogenase and bilirubin. Determination of serum total and direct bilirubin was done by using microplate reader (Power wave; Biotek Pvt. Ltd. Mumbai).

Hydroxyproline content in the liver: (Wardi et al., 2001): Small samples of liver tissue were hydrolyzed by $6 \mathrm{~N}$ $\mathrm{HCl}$ for 3 hours at $130^{\circ} \mathrm{C}$. Few drops of the methyl red indicator were added followed by $2.5 \mathrm{~N} \mathrm{NAOH}$ required for neutralization. Final adjustments were made with diluted $\mathrm{HCl}$ and $\mathrm{NAOH}$ until the indicator turned slightly yellow, corresponding to $\mathrm{pH} 6.0 \pm 7.0$. The concentrations of $\mathrm{NaCl}$ in the final dilutions did not exceed $0.4 \mathrm{M}$ as required. Samples of $2 \mathrm{~mL}$ were then oxidized by adding $1 \mathrm{~mL}$ chloramine $\mathrm{T}$ (Sodium $\mathrm{p}$ toluene sulfonchloramide). After $20 \mathrm{~min}$ of mixing and shaking the test tubes $1 \mathrm{~mL}$ perchloric acid was added to each tube. After $5 \mathrm{~min} 1 \mathrm{~mL}$ p-dimethylaminobenzaldehyde solution was added and the mixture was shaken for $5 \mathrm{~min}$. The tubes were placed in a $60^{\circ} \mathrm{C}$ water bath for $20 \mathrm{~min}$ and then cooled in tap water for $5 \mathrm{~min}$. The absorbance was measured at $557 \mathrm{~nm}$.

Histopathological examination: The rat liver was dissected out and fixed in $10 \%$ formalin and further processed for histopathological investigations.

Statistical analysis: The data were analyzed statistically by one way ANOVA followed by Dunnett's test. $p<0.05$ was considered as significant.

Estimation of anti-oxidant activity: Glutathione in vivo estimation was done to the same group of rats according to Beutler et al., 1963. The glutathione content of liver sample, in $\mu \mathrm{mol} / \mathrm{mg}$ of protein.

\section{Results}

Phytochemical investigation of methanol extract of $C$. hirsutus revealed presence of various active constituents Alkaloids, Glycosides and Amino acids.

The $\mathrm{LD}_{50}$ of plant methanolic extract was found to be $2,000 \mathrm{mg} / \mathrm{kg}$. The effective dose $200 \mathrm{mg} / \mathrm{kg}$ was selected based on $\mathrm{LD}_{50}$ of plant.

Hepatomegaly occurs due to accumulation of lipids and proteins in hepatocytes, with an impaired protein secretion by hepatocytes. Water is retained in the cytoplasm of hepatocytes leading to enlargement of liver cells, resulting in increased total liver mass and volume (Rao et al., 2007) which is expressed in Table I.

The activities of various biochemical enzymes in normal, Bile duct ligated, methanolic extract treated groups are expressed in Table II. In bile duct ligated control group there was significant rise in serum marker enzymes levels, compared to normal where as methanolic extract treated groups showed significant decrease in all enzyme level. There was significant rise in glutathione level of extract treated group as compared to bile duct ligated animals (Table III).

Histopathological findings showed that as compared to normal animals, the bile duct ligated animals showed necrosis, lymphocyte infiltration and portal inflammation (Figure 1). Sham treated animals showed normal liver histology and methanolic extract-treated animals showed decreased in the inflammation and fibrosis and restoring normal cell structure.

Table II

Biochemical estimation in bile duct ligated animals

\begin{tabular}{|c|c|c|c|c|c|c|c|}
\hline Group & $\begin{array}{c}\text { Aspartate } \\
\text { transami- } \\
\text { nase }(\mathrm{IU} / \mathrm{L})\end{array}$ & $\begin{array}{c}\text { Alanine } \\
\text { transami- } \\
\text { nase(IU/L) }\end{array}$ & $\begin{array}{c}\text { Alkaline } \\
\text { phosphatase } \\
(\mathrm{IU} / \mathrm{L})\end{array}$ & $\begin{array}{l}\text { Lactate dehy- } \\
\text { drogenase } \\
\text { (IU/L) }\end{array}$ & $\begin{array}{c}\text { Total } \\
\text { bilirubin } \\
\text { (\% mg) }\end{array}$ & $\begin{array}{c}\text { Direct } \\
\text { bilirubin } \\
\text { (\%mg) }\end{array}$ & $\begin{array}{c}\mathrm{HP} \\
(\mathrm{mg} / \mathrm{g})\end{array}$ \\
\hline Normal & $66 \pm 1.5$ & $49 \pm 1.3$ & $175 \pm 1.4$ & $150 \pm 1.3$ & $0.2 \pm 0.01$ & $0.1 \pm 0.0$ & $4.9 \pm 0.2$ \\
\hline Bile duct ligated & $154 \pm 1.6$ & $128 \pm 1.0$ & $424 \pm 1.5$ & $331 \pm 2.2$ & $0.8 \pm 0.02^{b}$ & $0.2 \pm 0.01$ & $13 \pm 0.2$ \\
\hline $\begin{array}{l}\text { Bile duct ligated }+ \\
\text { Silymarin }(50 \mathrm{mg} / \mathrm{kg})\end{array}$ & $84 \pm 0.9 b$ & $71 \pm 0.9 \mathrm{~b}$ & $198 \pm 1.1^{b}$ & $178 \pm 1.1^{b}$ & $0.2 \pm 0.01^{b}$ & $0.1 \pm 0.01^{b}$ & $7.2 \pm 0.2^{b}$ \\
\hline Sham treated & $62 \pm 2.7 b$ & $50 \pm 1.0^{\mathrm{b}}$ & $179 \pm 2.2^{b}$ & $149 \pm 1.7 \mathrm{~b}$ & $0.2 \pm 0.01^{b}$ & $0.01 \pm 0.01^{b}$ & $5.4 \pm 0.2^{b}$ \\
\hline $\begin{array}{l}\text { Bile duct ligated }+ \\
\text { Methanolic extract } \\
(100 \mathrm{mg} / \mathrm{kg})\end{array}$ & $134 \pm 2.9 \mathrm{~b}$ & $115 \pm 2.4^{b}$ & $394 \pm 7.8^{b}$ & $288 \pm 2.3^{b}$ & $0.7 \pm 0.02^{\mathrm{b}}$ & $0.2 \pm 0.01^{\mathrm{a}}$ & $12 \pm 0.5^{a}$ \\
\hline $\begin{array}{l}\text { Bile duct ligated + } \\
\text { Methanolic extract } \\
(200 \mathrm{mg} / \mathrm{kg})\end{array}$ & $113 \pm 1.7 \mathrm{~b}$ & $96 \pm 1.0^{\mathrm{b}}$ & $353 \pm 7.2^{b}$ & $249 \pm 4.6^{b}$ & $0.6 \pm 0.01^{b}$ & $0.2 \pm 0.0^{b}$ & $11 \pm 0.4^{\mathrm{b}}$ \\
\hline $\begin{array}{l}\text { Bile duct ligated }+ \\
\text { Methanolic extract } \\
(400 \mathrm{mg} / \mathrm{kg})\end{array}$ & $93 \pm 1.3^{b}$ & $81 \pm 0.7 b$ & $314 \pm 2.3^{b}$ & $229 \pm 3.0^{b}$ & $0.4 \pm 0.01^{b}$ & $0.2 \pm 0.01^{b}$ & $10 \pm 0.7 b$ \\
\hline
\end{tabular}




\begin{tabular}{|c|c|}
\hline \multicolumn{2}{|c|}{ Table III } \\
\hline \multicolumn{2}{|c|}{$\begin{array}{l}\text { Effect of methanol extract of Cocculus hirsutus } \\
\text { on glutathione level in bile duct ligated rats }\end{array}$} \\
\hline Group & $\begin{array}{l}\text { Gluthathione level } \\
\mu \mathrm{mol} / \mathrm{mg} \text { of protein }\end{array}$ \\
\hline Normal saline treated & $1.8 \pm 0.0$ \\
\hline Bile duct ligated & $0.8 \pm 0.0$ \\
\hline Silymarin treated $(50 \mathrm{mg} / \mathrm{kg})$ & $1.7 \pm 0.0$ \\
\hline $\begin{array}{l}\text { Cocculus hirsutus extract }(400 \\
\mathrm{mg} / \mathrm{kg})\end{array}$ & $1.4 \pm 0.0$ \\
\hline
\end{tabular}

\section{Discussion}

Liver fibrosis is major feature of wide range of chronic liver injuries including metabolic, viral, cholestatic and genetic. The proliferation of the bile ducts (ductular reaction) of the liver in response to various liver injuries is characterized by an increase in the number of intrahepatic bile ducts (Yoshioka et al., 2005). In the present study hepatic damage with fibrosis was produced by common bile duct ligation for 28 days. Bile duct ligation is associated with hepatic dysfunction includes the oxidative damage to mitochondrial proteins and lipids and cytotoxicity of bile acids. Release of reactive oxygen species (free radicals) leads to cell damage.
The hepatic stellate cells (Ito cells, hepatic lipocytes, or fat-storing cells) play an important role in the pathogenesis of hepatic fibrosis, cirrhosis, and liver remodeling. After liver injury, hepatic stellate cells undergo activation and transdifferentiation to myofibroblast-like cells. a-SMA is a marker for myofibroblast-like cells (Tieppo et al., 2005).

Bile duct ligation also induces oxidative stress which leads to formation of free radicals and lipid peroxidation (Tieppo et al., 2005). Significant rise in the aspartate transaminase, alanine transaminase, alkaline phosphatase, lactate dehydrogenase, hydroxyproline, total bilirubin, direct bilirubin level and marked reduction in the levels of above mentioned enzymes were observed with methanolic extract of $C$. hirsutus treatment.

The body has an effective defense mechanism to prevent and neutralize the free radical induced damage. This is accomplished by a set of endogenous antioxidant enzymes such as superoxide dismutase, catalase and GSH etc. These enzymes constitute a mutually supportive team of defense against reactive oxygen species. Bile duct ligation induces imbalance between reactive oxygen species production and these anti-oxidant defense which results into oxidative stress through a series of events deregulates the cellular functions leading to hepatic damage (Sanmugapriya

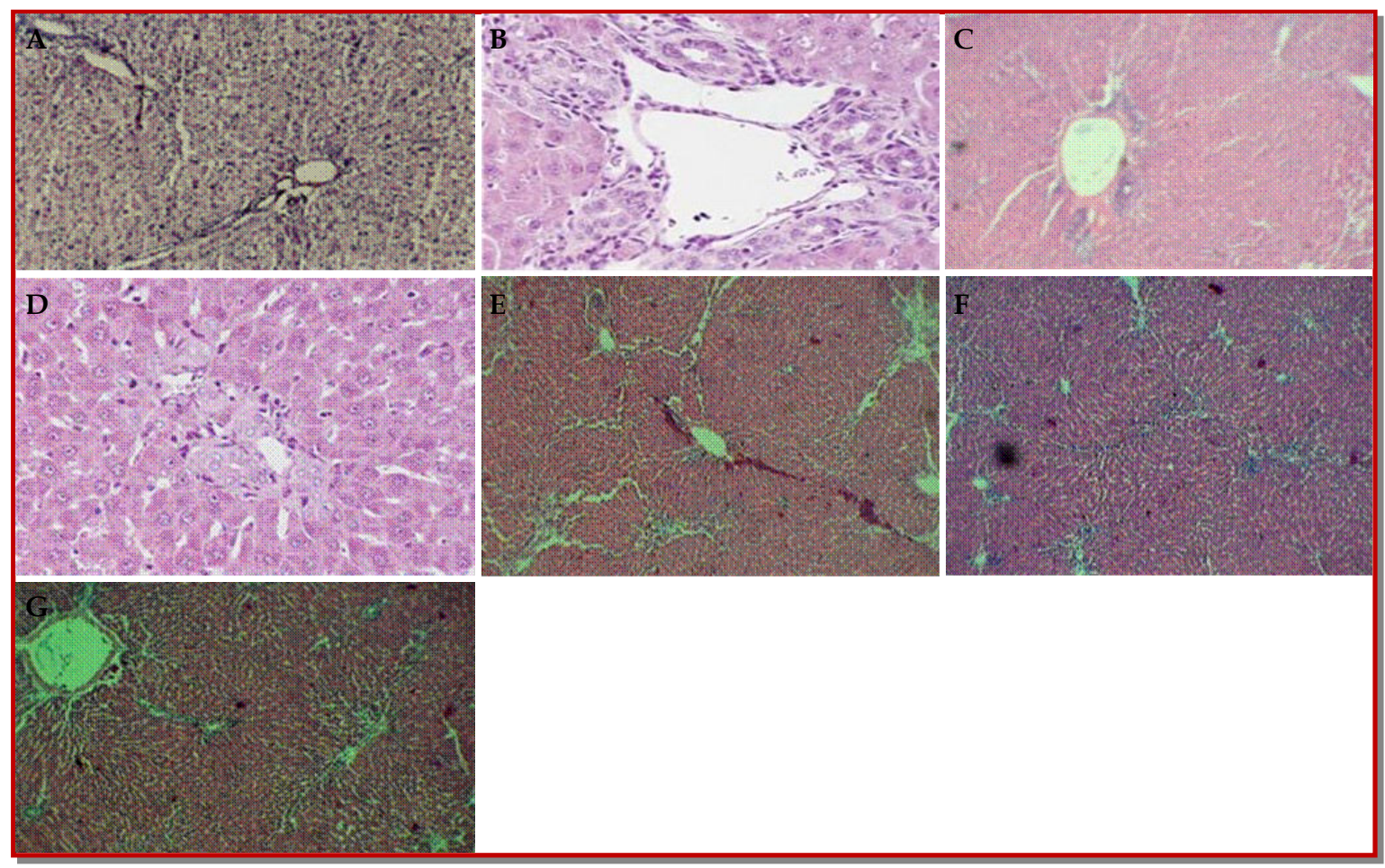

Figure 1: (A) Histology of normal liver showing normal hepatocyte, prominent central vein and sinosoids; (B) Bile duct ligated liver showing necrosis and portal inflammation, lymphocyte infiltration; C) Sham treated liver showing normal liver histology, prominent central vein and hepatocytes; D) Silymarin-treated liver showing necrosis and portal inflammation decreases compared with bile duct ligation; E) Methanol extract $(100 \mathrm{mg} / \mathrm{kg})$ showing mild bile duct proliferation and portal inflammation; F) Methanol extract $(200 \mathrm{mg} / \mathrm{kg})$ showing few area of necrosis and fatty change are seen; G) Methanol extract (400 mg/ kg) showing small areas of lymphocyte infiltration and restoration of cells near to normal are seen (Hematoxylin and Eosin stain X 100) 
and Venkataraman, 2006).

The anti-oxidant and hepatoprotective effects of $C$. hirsutus could be due to presence of phytochemicals like B-sitosterol, trilobine, isotrilobine, syringaresionol, protoquercitol, ginnol and glycosides (Palsamy et al., 2007; Jayakar and Sangameswaran, 2007).

\section{Conclusion}

The methanolic extract of C. hirsutus shows hepatoprotective and anti-oxidant activity.

\section{Acknowledgement}

Authors are thankful to Principal S. J. Surana, R. C. Patel IPER for providing the necessary facilities for carrying out this research work.

\section{References}

Balamurugan G, Muthusamy P. Observation of the hepatoprotective and antioxidant activities of Trianthema decandra Linn. (Vallai sharunnai) roots on carbon tetrachloride-treated rats. Bangladesh J Pharmacol. 2008; 3: 83-89.

Buetler E, Duron O, Kelly BM. Proved method for determination of blood glutathione. J Lab Clin Med. 1963; 61: 882-87.

D'SOUZA M. Tribal Medicine. Social center, Ahmednagar, 1st ed. India, 1998, pp 143-44.

Ganapaty S, Dash GK, Suresh P. Diuretic, laxative and toxicity studies of Cocculus hirsutus aerial parts. Fitoterapia 2002; 73: 28-31.

Ganapaty S, Vijay K. Hypoglycemic activity of aerial parts of Cocculus hirsutus on alloxan-induced diabetes. Indian J Nat Prod. 2006; 22: 17-20.

Iqbal MJ, Dewan ZF, Choudhury SAR, Mamun MIR, Mashiuzzaman M, Begum M. Pre-treatment by hexane extract of Phyllanthus niruri can alleviate paracetamolinduced damage of the rat liver. Bangladesh J Pharmacol. 2007; 2: 43-48.

Jayakar B, Sangameswaran B. Anti-diabetic and spermatogenic activity of Cocculus hirsutus (L) diels. African J Biotech. 2007; 6: 1212-16.

Kirtikar KR, Basu BD. Indian medicinal plants. $2^{\text {nd }}$ ed. India, International Book Publishers, 1987, pp 86-87.

Kokate CK, Purohit AP, Gokhale SB. Pharmacognosy, 26th ed. India, Nirali Prakashan, 2004, pp 101-10.

Lee TY, Chang HH, Chenjenn H. Herb medicine ameliorates hepatic fibrosis in bile duct ligation rats. J Ethnopharmacol. 2007; 109: 318-24
Lin CC, Yen MH, Lo TS, Lin JM. Evaluation of the hepatoprotective and anti-oxidant activity of Boehmeria nivea var. nivea and B. nivea var. tenacissima. J Ethnopharmacol. 1998; 60: 9-17.

OECD Guidelines for the testing of chemicals revised draft guideline 425: Acute oral toxicity-2001. Acute toxic class method.

Palsamy P, Malathi R. Evaluation of hypoglycemic and hypolipidemic activity of methanolic extract of Cocculus hirsutus (L) diels leves in streptozotocin-induced diabetes mellitus rats. Int J Biol Chem. 2007; 1: 205-12.

Panda BK, Mishra US. Antibacterial activity of the leaves of Cocculus hirsutus. Indian Drugs, 2007; 44: 108-10.

Rao VN, Patil N, Shalam MD. Hepatoprotective activity of alcoholic and aqueous extracts of leaves of Tylophora indica (Linn) in rats. Indian J Pharmacol. 2007; 39: 43-47.

Sanmugapriya E, Venkataraman S. Studies on hepatoprotective and anti-oxidant actions of Strychnos potatoram Linn. seeds on $\mathrm{CCl}_{4}$ induced acute hepatic injury in experimental rats. J Ethnopharmacol. 2006; 105: 154-60.

Saraswat B, Visen PKS, Patnaik GK, Dhawan BN. Ex vivo and in vivo investigations of picroliv from Picrorhiza kurrooa and in alcohol intoxication model in rats. J Ethnopharmacol. 1999; 66: 263-69.

Saxena AK, Singh B, Anand KK. Hepatoprotective effects of Eclipta alba on subcellular levels in rats. J Ethnopharmacol. 1993; 40: 155-16.

Tieppo J, Vercelino R, Dias AS, Marroni CA, Marroni N. Common bile duct ligation as a model of hepatopulmonary syndrome and oxidative stress. Arq Gastroenterol. 2005; 42: 244-48.

Torres-Durain PV, Miranda-Zamora R, Paredes Carbajal MC, Mascher D, Bie-Castillo J, Diaz-Zagoya JC. Studies on the preventive effect of Spirulina maxima on fatty liver development by carbon tetrachloride in the rat. J Ethnopharmacol. 1999; 64: 141-47.

Vogel GH, Vogel WH. Drug discovery and evaluation. Pharmacological Assays. 2nd ed. Germany. Springer 2002, pp 936-44.

Wang G, Shen H, Rajaraman G, Roberts MS, Gong Y, Jiang P, Burczynsk F. Expression and antioxidant function of liver fatty acid binding protein in normal and bile-duct ligated rats. Eur J Pharmacol. 2007; 560: 61-68.

Wardi J, Reifen R, Aeed H, Zadel L, Avni Y, Bruck R. Beta carotene attenuates experimentally induced liver cirrhosis in rats. Isr Med Assoc J. 2001; 3: 151-54.

Yoshioka K, Mori A, Taniguchi K, Mutoh K. Cell proliferation activity of proliferating bile duct after bile duct ligation in rats. Vet Pathol. 2005; 42: 382-85.

Zafar R, Ali SM. Anti-hepatotoxic effects of root and root callus of Cichorium intybus. J Ethnopharmacol. 1998; 63: 227-31. 